\title{
INVESTIGATION OF WATER QUALITY IN AMBUR CITY BY WATER QUALITY INDEXING
}

\author{
K. Mohiuddin Farooqui ${ }^{*}$, Santosh Kumar Sar ${ }^{* *}$, Vijita Diwan ${ }^{* * *}$ \\ ${ }^{*}$ Vellore Institute of Technology, Vellore, India \\ ${ }^{* * *}$ Bhilai Institute of Technology, Department of Applied Chemistry, Durg, India \\ *** Shri Shankaracharya Technical Campus, Department of Applied Chemistry, Bhilai, India \\ corresponding author: K. Mohiuddin Farooqui, e-mail: mohi.farooqui@gmail.com
}

\begin{abstract}
Present study is carried out for the assessment of ground water quality and comparing its suitability for drinking purpose in Ambur city in Tirupattur District, Tamil Nadu, India. Water quality index is calculated on the basis of $\mathrm{pH}$, conductivity, total dissolved solids, total hardness, $\mathrm{Ca}^{2+}, \mathrm{Mg}^{2+}, \mathrm{Na}^{+}$, $\mathrm{K}^{+}, \mathrm{Cl}^{-}$, alkalinity, and $\mathrm{SO}_{4}{ }^{2-}$ content of the water samples. Water quality index study show that the ground water quality of the study area is deteriorated due to high value of total dissolved solids, conductivity, total hardness, calcium, magnesium, chloride, and sulphate in water samples.
\end{abstract}

Keywords: Ambur city, water quality index, total dissolved solids, total hardness, ground water quality

\section{INTRODUCTION}

Groundwater is ultimate, most suitable fresh water resource for millions of people for both drinking and irrigation. Ground water was considered to be very clean and safe in past but nowadays it is getting contaminated due to rapid industrialization and increasing human population. The groundwater quality in any area is determined by its physical and chemical parameters which depend on geological formations, climatic conditions and anthropogenic activities. Both the natural (such as weathering of rocks and leaching of soils, dissolution of aerosol particles from the atmosphere) and anthropogenic activities (such as mining, processing and the use of metalbased materials, agricultural practices) have resulted in contamination of ground water [1]. Faecal pollution of drinking water causes water born disease which has led to the death of millions of people [2, 3]. Wastes from manufacturing, power-generating, mining, construction, and food processing industries are the major sources for water pollution [4]. It is found that $70-80 \%$ of water pollution is due to the untreated domestic sewage $[5,6]$. Nowadays, the use of synthetic fertilizers, pesticides and herbicides in farming and gardening has become common around the world. When these chemicals enter into water bodies, they can cause disease in humans and 
animals. These chemicals had an adverse effect on ground water quality [7]. Hepatitis, typhoid, diarrhoea, and dysentery are the common diseases which are caused by contaminated water [4]. It is very essential and important to check the water before it is used for drinking, domestic, agricultural or industrial purpose. Water must be tested with different physico-chemical parameters. Water quality index provides a single number that expresses overall water quality at a certain location and time, based on several water quality parameters. The objective of water quality index is to turn complex water quality data into information that is understandable and usable by the public. In general, water quality indices incorporate data from multiple water quality parameters into a mathematical equation that rates the health of a water body with number. In this study, for the calculation of water quality index, eleven important parameters were chosen. The objective of this study is to analyse the ground water quality in the town of Ambur. This study highlights the contamination of water in Ambur.

\section{Study Area}

Ambur is a town in Tirupattur District, Tamil Nadu, India. It is an industrial area comprising many tannery industries. Due to excessive industrial effluents over the year, it has made the ground water and surface water in the region unfit for any use, be it for drinking or irrigational purpose. Figure 1 shows the geographic location of Ambur city.

\section{EXPERIMENTAL}

To analyse the contamination of water, 16 ground water samples were collected from different locations in the area chosen in January 2019. In this study, 12 physicochemical parameters $(\mathrm{pH}$, total dissolved solids (TDS), conductivity, turbidity, alkalinity, hardness, calcium, magnesium, sulphate, chloride, sodium, and potassium) were analysed.
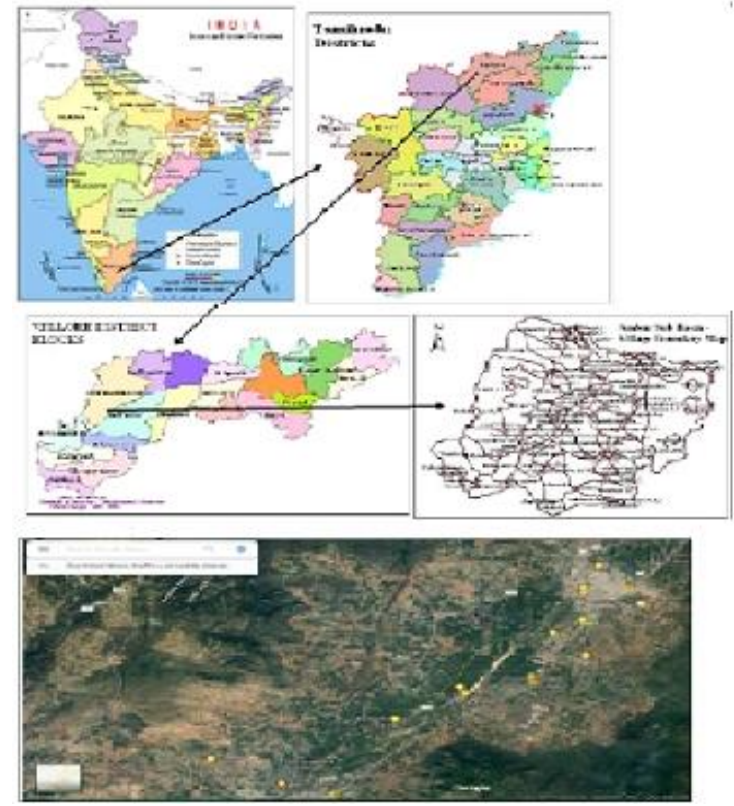

Figure 1. Map of study area (Ambur city)

\section{Physiochemical parameters}

Testing of $\mathrm{pH}$ was carried out with the use of aquasol $\mathrm{pH}$ meter (Model AM-PH-01) at the time of collection of samples. Turbidity measurement is based on a comparison of the intensity of light scattered by a sample and a standard reference under the same conditions. Turbidity is measured by Deluxe turbidity meter (Digital Turbidity meter ME 988, by Max Electronics India). TDS is calculated by the evaporation method. Testing of conductivity was carried out with the use of digital conductivity meter (model No: 611 by Electronics India). The determination of chloride is made by $\mathrm{AgNO}_{3}$ titration (Mohr's titration). Total hardness $(\mathrm{TH})$, calcium and magnesium determination is carried out by complexometric titration using sodium salt of ethylene-diamine tetra acetic acid (EDTA). The concentration of sodium and potassium in the water samples were determined by flame photometer (systronic, model No: 128). Alkalinity was measured by titrating the water samples with standard acid using phenolphthalein and methyl orange as indicator. Sulphate content of water samples was measured with the turbidity method. 


\section{Water quality index}

Water quality index (WQI) is calculated on the basis of eleven important water quality parameters $\left(\mathrm{pH}\right.$, conductivity, TDS, $\mathrm{TH}, \mathrm{Ca}^{2+}$, $\mathrm{Mg}^{2+}, \mathrm{Na}^{+}, \mathrm{K}^{+}, \mathrm{Cl}^{-}$, alkalinity and $\left.\mathrm{SO}_{4}{ }^{2-}\right)$. The WQI has been calculated by using the standards of drinking water quality recommended by the Bureau of Indian Standards (BIS) [8] and Indian Council for Medical Research (ICMR) [9]. The weighted arithmetic index method [10] has been used for the calculation of WQI of the drinking water samples collected from various locations in Ambur.

Further, quality rating or sub index $\left(\mathrm{q}_{\mathrm{n}}\right)$ was calculated using the following expression:

$$
\mathrm{q}_{\mathrm{n}}=100\left[\mathrm{~V}_{\mathrm{n}}-\mathrm{V}_{\mathrm{io}}\right] /\left[\mathrm{S}_{\mathrm{n}}-\mathrm{V}_{\mathrm{io}}\right]
$$

where is: $\mathrm{q}_{\mathrm{n}}$ - quality rating for the $\mathrm{n}$-th water quality parameter, $V_{n}$ - estimated value of the $\mathrm{n}$-th parameter at a given sampling station, $\mathrm{S}_{\mathrm{n}}$ standard permissible value of the $n$-th parameter, $V_{\text {io }}$ - ideal value of $n$-th parameter in pure water (i.e., 0 for all other parameters except the parameter $\mathrm{pH}$ and dissolved oxygen ( 7.0 and $14.6 \mathrm{mg} / \mathrm{l}$ respectively)

Unit weight was calculated by a value inversely proportional to the recommended standard value $S_{n}$ of the corresponding parameter:

$$
\mathrm{W}_{\mathrm{n}}=\frac{\mathrm{K}}{\mathrm{S}_{\mathrm{n}}}
$$

where is: $W_{n}$ - unit weight for the $n$-th parameters, $S_{n}-$ standard value for $n$-th parameters, $\mathrm{K}$ - constant for proportionality.

The overall WQI was calculated by aggregating the quality rating with the unit weight linearly:

$$
\mathrm{WQI}=\frac{\sum \mathrm{q}_{\mathrm{n}} \mathrm{W}_{\mathrm{n}}}{\sum \mathrm{W}_{\mathrm{n}}}
$$

\section{RESULTS AND DISCUSSION}

\section{Physiochemical parameters}

Details of physicochemical parameters at various locations of the study area have been tabulated and shown in Table 1. Range of the $\mathrm{pH}$ lies between 7.1 to 8.4 , which follows the standards (Table 2) given by Council of Medical Research (ICMR 1975) and Bureau of Indian Standards (BIS 2012). The value of electrical conductivity (EC) ranges from 620 $4984 \mu \mathrm{S} / \mathrm{cm}$ in study area. TDS found to be in the range of $395.5-3250 \mathrm{mg} / \mathrm{l}$. About $63 \%$ of the water samples had TDS above the limit $(500 \mathrm{mg} / \mathrm{l})$ set by BIS. High level of TDS indicating poor water quality in the study area. Turbidity falls in the range of 11.6 - 55 NTU. All samples had turbidity value greater than the ICMR and BIS recommended limit. The hardness values are within the range of 50 $1587.5 \mathrm{mg} / \mathrm{l}$. Calcium and magnesium ions from sedimentary rocks, seepage and runoff from soils are the sources of hardness in water. Based on ICMR limit, $94 \%$ of the collected water samples had alkalinity above the maximum permissible limit of $120 \mathrm{mg} / \mathrm{l}$. The concentration of sodium and potassium in the study area varies from $0.5-97.1 \mathrm{mg} / \mathrm{l}$ and from $0-22.5 \mathrm{mg} / \mathrm{l}$ respectively. $100 \%$ of the water samples had chloride content above the ICMR limit. High value of chloride may be due to contamination from a tannery industry.

\section{Water quality index}

The WQI values of the samples are summarized in Table 3. WQI values in the study area range from 73.6 to 491.5. The WQI classification [11] shows that $19 \%$ of water samples have very poor water status, $6 \%$ of water samples have poor water status, and 75 $\%$ of water samples have been found unsuitable for drinking. This may be due to the location of the study area which is dominated by tannery industries and construction activities. Excellent water quality has not been observed in any location in the study area. 
Table 1. Water quality data of Ambur city

\begin{tabular}{|c|c|c|c|c|c|c|c|c|c|c|c|c|c|c|}
\hline $\begin{array}{c}\text { Sample } \\
\text { ID }\end{array}$ & Place & Coordinates & $\mathrm{pH}$ & $\begin{array}{c}\text { Conductivity } \\
(\mu \mathrm{S} / \mathrm{cm})\end{array}$ & $\begin{array}{l}\text { TDS } \\
(\mathrm{mg} / \mathrm{l})\end{array}$ & $\begin{array}{l}\text { Turbidity } \\
\text { (NTU) }\end{array}$ & $\begin{array}{c}\mathrm{TH} \\
(\mathrm{mg} / \mathrm{l})\end{array}$ & $\begin{array}{c}\text { Calcium } \\
(\mathrm{mg} / \mathrm{l})\end{array}$ & $\underset{(\mathrm{mg} / \mathrm{l})}{\text { Magnesium }}$ & $\begin{array}{l}\text { Alkalinity } \\
(\mathrm{mg} / \mathrm{l} \text { as } \\
\left.\mathrm{CaCO}_{3}\right)\end{array}$ & Sodium & $\begin{array}{c}\text { Potassium } \\
(\mathrm{mg} / \mathrm{l})\end{array}$ & $\begin{array}{c}\text { Sulphate } \\
(\mathrm{mg} / \mathrm{l})\end{array}$ & $\begin{array}{r}\text { Chloride } \\
(\mathrm{mg} / \mathrm{l})\end{array}$ \\
\hline WD1 & Udayendram & $\begin{array}{l}12^{\circ} 41^{\prime} 34.0^{\prime \prime} \mathrm{N} \\
78^{\circ} 37^{\prime} 05.3^{\prime \prime} \mathrm{E}\end{array}$ & 8.4 & 685.8 & 470.32 & 18.9 & 52.5 & 12 & 5.4 & 135 & 7.01 & 0 & 7.19 & 799.68 \\
\hline WD2 & Pallipattu & $\begin{array}{l}12^{\circ} 27^{\prime} 28.5 " \mathrm{~N} \\
78^{\circ} 34^{\prime} 05.6^{\prime \prime} \mathrm{E}\end{array}$ & 8.3 & 630.2 & 410.65 & 16 & 50 & 22 & 0 & 125 & 7.61 & 0 & 6.09 & 599.8 \\
\hline WD3 & Veliagaram & $\begin{array}{l}13^{\circ} 19^{\prime} 30.1^{\prime \prime} \mathrm{N} \\
79^{\circ} 26^{\prime} 23.2^{\prime \prime} \mathrm{E}\end{array}$ & 7.7 & 619.8 & 395.55 & 26.5 & 197.5 & 118 & 0 & 355 & 12.65 & 10 & 100.81 & 749.6 \\
\hline WD4 & Chinnapallikuppam & $\begin{array}{l}12^{\circ} 43^{\prime} 24.0^{\prime \prime} \mathrm{N} \\
78^{\circ} 39^{\prime} 13.5^{\prime \prime} \mathrm{E}\end{array}$ & 8.3 & 689.7 & 425.76 & 13.1 & 55 & 16 & 3.6 & 145 & 3.29 & 13 & 49.83 & 599.8 \\
\hline WD5 & Melkrishnapuram & $\begin{array}{l}12^{\circ} 47^{\prime} 02.8^{\prime \prime} \mathrm{N} \\
78^{\circ} 42^{\prime} 40.1^{\prime \prime} \mathrm{E}\end{array}$ & 7.6 & 708.5 & 487.21 & 26.7 & 195 & 98 & 0 & 290 & 12.3 & 21.2 & 101.57 & 699.6 \\
\hline WD6 & Kethandapatty & $\begin{array}{l}12^{\circ} 55^{\prime} 45.1^{\prime \prime N} \\
78^{\circ} 21^{\prime} 01.2^{\prime \prime} \mathrm{E}\end{array}$ & 8 & 658.5 & 425.23 & 12.5 & 175 & 58 & 7.2 & 320 & 0.54 & 18.2 & 47.55 & 649.6 \\
\hline WD7 & Dharmapuri & $\begin{array}{l}12^{\circ} 12^{\prime} 33.3^{\prime \prime} \mathrm{N} \\
78^{\circ} 06^{\prime} 05.1^{\prime \prime} \mathrm{E}\end{array}$ & 7.5 & 810.52 & 524.22 & 25.6 & 275 & 106 & 2.4 & 455 & 54.35 & 12.1 & 97.38 & 999.6 \\
\hline WD8 & Vaatimanai & $\begin{array}{l}12^{\circ} 47^{\prime} 49.3^{\prime \prime N} \\
78^{\circ} 42^{\prime} 53.8^{\prime \prime} \mathrm{E}\end{array}$ & 7.8 & 907.6 & 615.82 & 28.1 & 212.5 & 94 & 0 & 315 & 9.81 & 13.1 & 106.89 & 599.8 \\
\hline WD9 & Maniyarakuppam & $\begin{array}{l}12^{\circ} 44^{\prime} 23.5^{\prime \prime} \mathrm{N} \\
78^{\circ} 40^{\prime} 13.1^{\prime \prime} \mathrm{E}\end{array}$ & 8.2 & 925.4 & 632.23 & 11.6 & 62.5 & 22 & 1.8 & 100 & 7.58 & 22.5 & 11.60 & 599.8 \\
\hline WD10 & Sanankuppam & $\begin{array}{l}12^{\circ} 46^{\prime} 31.3^{\prime \prime N} \\
78^{\circ} 42^{\prime} 09.4^{\prime \prime} \mathrm{E}\end{array}$ & 7.7 & 845.9 & 576.25 & 14.5 & 150 & 42 & 10.8 & 320 & 21.49 & 11.79 & 14.50 & 649.6 \\
\hline WDI1 & Periyankuppam & $\begin{array}{l}12^{\circ} 45^{\prime} 09.5^{\prime \prime} \mathrm{N} \\
78^{\circ} 42^{\prime} 02.8^{\prime \prime} \mathrm{E}\end{array}$ & 7.2 & 2885 & 1850 & 48.7 & 1100 & 701 & 0 & 330 & 82.96 & 10.14 & 370.51 & 2149.2 \\
\hline WDI2 & Vinnamangalam & $\begin{array}{l}12^{\circ} 44^{\prime} 42.2^{\prime \prime} \mathrm{N} \\
78^{\circ} 41^{\prime} 30.0^{\prime \prime} \mathrm{E}\end{array}$ & 7.2 & 3558 & 2425 & 38.4 & 1542.5 & 822 & 0 & 340 & 29.76 & 0 & 292.15 & 3448.8 \\
\hline WDI3 & Minnur & $\begin{array}{l}12^{\circ} 44^{\prime} 03.1^{\prime \prime} \mathrm{N} \\
78^{\circ} 40^{\prime} 17.9^{\prime \prime} \mathrm{E}\end{array}$ & 7.4 & 2774 & 1520 & 12.8 & 1587.5 & 982 & 0 & 280 & 37.05 & 12.5 & 486.91 & 4098.6 \\
\hline WDI4 & Gandhi nagar & $\begin{array}{l}12^{\circ} 46^{\prime} 26.7 " \mathrm{~N} \\
78^{\circ} 43^{\prime} 40.8^{\prime \prime} \mathrm{E}\end{array}$ & 7.5 & 4568 & 3080 & 55 & 725 & 561 & 0 & 330 & 97.11 & 0 & 418.44 & 2149.2 \\
\hline WDI5 & Sanan Kuppa & $\begin{array}{l}12^{\circ} 46^{\prime} 27.5^{\prime \prime} \mathrm{N} \\
78^{\circ} 42^{\prime} 34.8^{\prime \prime} \mathrm{E}\end{array}$ & 7.9 & 4984 & 3250 & 14.2 & 212.5 & 60 & 15 & 325 & 7.86 & 11.03 & 108.03 & 699.6 \\
\hline WDI6 & Ambur Plantation & $\begin{array}{l}12^{\circ} 45^{\prime} 57.0^{\prime \prime} \mathrm{N} \\
78^{\circ} 43^{\prime} 00.9^{\prime \prime} \mathrm{E}\end{array}$ & 7.1 & 3048 & 2042 & 45 & 775 & 481 & 0 & 370 & 20.39 & 11.76 & 258.67 & 2049.2 \\
\hline
\end{tabular}

Table 2. Drinking water standards and recommending agencies

\begin{tabular}{|r|c|c|c|}
\hline $\begin{array}{c}\mathrm{S} \\
\text { No. }\end{array}$ & Parameters & Standards & $\begin{array}{c}\text { Recommended } \\
\text { agency }\end{array}$ \\
\hline 1. & $\mathrm{pH}$ & $6.5-8.5$ & ICMR/BIS \\
\hline 2. & $\begin{array}{c}\text { Electrical } \\
\text { conductivity } \\
(\mu \mathrm{S} / \mathrm{cm})\end{array}$ & 300 & ICMR \\
\hline 3. & $\begin{array}{c}\text { Total dissolved } \\
\text { solids }(\mathrm{mg} / \mathrm{l})\end{array}$ & 500 & ICMR/BIS \\
\hline 4. & $\begin{array}{c}\text { Turbidity } \\
(\mathrm{NTU})\end{array}$ & 5 & ICMR/BIS \\
\hline 5. & Hardness $(\mathrm{mg} / \mathrm{l})$ & 300 & ICMR \\
\hline 6. & Calcium $(\mathrm{mg} / \mathrm{l})$ & 75 & ICMR/BIS \\
\hline 7. & $\begin{array}{c}\text { Magnesium } \\
(\mathrm{mg} / \mathrm{l})\end{array}$ & 30 & ICMR/BIS \\
\hline 8. & $\begin{array}{c}\text { Alkalinity } \\
(\mathrm{mg} / \mathrm{l})\end{array}$ & 120 & ICMR \\
\hline 9. & Sodium $(\mathrm{mg} / \mathrm{l})$ & 50 & BIS/WHO \\
\hline 10. & $\begin{array}{c}\text { Potassium } \\
(\mathrm{mg} / \mathrm{l})\end{array}$ & 12 & BIS/WHO \\
\hline 11. & Sulphate $(\mathrm{mg} / \mathrm{l})$ & 150 & ICMR/BIS \\
\hline 12. & $\begin{array}{c}\text { Chlorides } \\
(\mathrm{mg} / \mathrm{l})\end{array}$ & 250 & ICMR \\
\hline
\end{tabular}

Table 3. WQI values of samples

\begin{tabular}{|c|c|c|}
\hline $\begin{array}{c}\text { Sample } \\
\text { ID }\end{array}$ & WQI & Water quality status \\
\hline WD1 & 86.9 & Very poor \\
\hline WD2 & 73.6 & Poor \\
\hline WD3 & 117.2 & Unsuitable for drinking \\
\hline WD4 & 89 & Very poor \\
\hline WD5 & 120.8 & Unsuitable for drinking \\
\hline WD6 & 133.4 & Unsuitable for drinking \\
\hline WD7 & 161.4 & Unsuitable for drinking \\
\hline WD8 & 158.4 & Unsuitable for drinking \\
\hline WD9 & 97.6 & Very poor \\
\hline WD10 & 121.7 & Unsuitable for drinking \\
\hline WD11 & 386.2 & Unsuitable for drinking \\
\hline WD12 & 473.45 & Unsuitable for drinking \\
\hline WD13 & 491.5 & Unsuitable for drinking \\
\hline WD14 & 445.1 & Unsuitable for drinking \\
\hline WD15 & 316.2 & Unsuitable for drinking \\
\hline WD16 & 345.7 & Unsuitable for drinking \\
\hline
\end{tabular}




\section{CONCLUSION}

Study of physicochemical parameters of the ground water of Ambur city indicates excess amount of TDS, EC, total hardness, calcium, magnesium, chloride and sulphate in water samples. The majority of water samples were found to be beyond desirable limits as prescribed by ICMR and BIS. Natural weathering, anthropogenic sources, excess groundwater extraction, and different polluting agents from tannery industry are contaminating the groundwater in the study area. The overall view of higher WQI of the present study indicates the deteriorated water quality and therefore it is unsuitable for human consumption. Hence, regular investigation of groundwater quality is required to observe the rate and type of contamination.

\section{REFERENCES}

[1] S.O. Adefemi, E.E. Awokunmi, Determination of physico-chemical parameters and heavy metals in water samples from Itaogbolu area of OndoState, Nigeria, African Journal of Environmental Science and Technology 4(2010) 3, 145-148.

[2] N. Sasakova, G. Gregova, D. Takacova, J. Mojzisova, I. Papajova, J. Venglovsky, T. Szaboova, S. Kovacova, Pollution of surface and ground water by sources related to agricultural activities, Frontiers in Sustainable Food Systems 2(2018), Article number 42.

[3] B. Fridrich, D. Krčmar, B. Dalmacija, J. Molnar, V. Pešić, M. Kragulj, N. Varga, Impact of wastewater from pig farm lagoons on the quality of local groundwater, Agricultural Water Management 135(2014), 40-53.

[4] R.S. Gambhir, V. Kapoor, A. Nirola, R. Sohi, V. Bansal, Water pollution: Impact of pollutants and new promising techniques in purification process, Journal of Human Ecology 37(2012) 2, 103-109.
[5] M. Haseena, M.F. Malik, A. Javed, S. Arshad, N. Asif, S. Zulfiqar, J. Hanif, Water pollution and human health, Environmental Risk Assessment and Remediation 1(2017) 3, 16-19.

[6] S. Ahmed, S. Ismail, Water pollution and its sources, effects \& management: A case study of Delhi, International Journal of Current Advanced Research 7(2018) 2, 10436-10442.

[7] G.R. Hallberg, The impacts of agricultural chemicals on ground water quality, GeoJournal 15(1987) 3, 283295.

[8] BIS (Bureau of Indian Standards) 10500, Specification for Drinking Water, Indian Standards Institution, New Delhi, 2012.

[9] ICMR (Indian Council of Medical Research), Manual of Standards of Quality for Drinking Water Supplies, Indian, Special Report No. 44, 1975.

[10] R.M. Brown, N.I. McLellend, R.A. Deininger, M.F. O'Connor, A water quality index - Crashing the psychological barrier, Indicators of Environmental Quality 1(1972), 173182.

[11] C. Chatterji, M. Raziuddin, Determination of water quality index (WQI) of a degraded river in Asansol industrial area, Raniganj, Burdwan, West Bengal, Nature, Environment and Pollution Technology 1(2002) 2, 181189.

\section{Acknowledgements}

Authors are thankful to the Professor Bhaskar Das, Vellore Institute of Technology, for valuable suggestions, guidance, and providing lab facility for this work. 